\title{
Haematological Changes in Broiler Birds with Induced Caecal Coccidiosis following Prophylaxis with Different Coccidiostats
}

\author{
N.D. Hirani", J.J. Hasnani, S.S. Pandya and P.V. Patel \\ Department of Veterinary Parasitology, College of Veterinary Science \& AH, Anand \\ Agricultural University, Anand-388001, Gujarat, India \\ *Corresponding author
}

\section{Keywords}

Broiler, Caecal coccidiosis, Coccidiostats, Haematology, Maduramicin, Salinomycin

Article Info

Accepted:

10 March 2018 Available Online: 10 April 2018

\section{A B S T R A C T}

The study was undertaken on Cobb-400 strain of broiler birds $(n=300)$ reared on battery cage system with standard protocols to know the comparative efficacy of 4 commonly used coccidiostats through haematological alterations in experimentally $E$. tenella infected birds. Fifty day-old chicks each of T1, T2, T3 and T4 group were given coccidiostat Diclazuril (0.1\%), Salinomycin (12\%), Diclazuril + Salinomycin and Maduramicin (1\%) at a dose rate of 100, 50, 100+50 and $50 \mathrm{~g} / 100 \mathrm{~kg}$ feed, respectively. Group T5 was kept as infected control and T6 as uninfected control without coccidiostat. Infection of E. tenella @ 50,000 oocytes was induced at three week of age in group T1 to T5 to see haematological changes after 1 wk of infection. The study revealed that haemoglobin, packed cell volume and total erythrocytes counts were reduced significantly $(\mathrm{P}<0.05)$, while total leukocytes counts were increased significantly on account of coccidial infection in all coccidiostat treated and infected non-treated control group of birds 1-week post-exposure. Differential leukocytes count (DLC) revealed significant increase in heterophills, lymphocytes and eosinophills, and decrease in monocytes and basophils in infected birds. Comparative less pathological change was found in Salinomycin treatment group. In comparison with positive control group, all coccidiostat treated groups and Maduramicin in particular showed significant beneficial effect on TEC with less RBCs damage. There was also significant reduction in PCV in post-infection positive control group compared to all coccidiostats treated groups. Better efficacy on PCV was of Salinomycin. TLC count of post infection positive control group was significantly higher than the pre-infection value of same group. Better efficacy on TLC of Salinomycin followed by Maduramicin was observed in E. tenella infection. After experimental infection heterophills counts were significantly increased in all treatment groups with highest increase in T1 group followed by T3, T4 and T2 group indicating better efficacy of Salinomycin and Maduramicin. Post-infection positive control group had significant increase in lymphocytes count as compared to pre-infection. Overall, better efficacy of Salinomycin followed by Maduramicin was found in infected birds compared to Diclazuril in terms of haematological alterations in experimentally infected birds. 


\section{Introduction}

Broiler production is one of the best ways of supplying good quality animal protein for human consumption. Broilers are the quickest, most economic and the most efficient converter of plant material into food of high biological value (Bootwalla, 2005). Poultry sector is however still confronted with many enteric diseases like coccidiosis which are hindering its progress (Saima et al., 2010), particularly in tropical countries (Chakrabarti, 1989). Coccidiosis is a widely known, greatly studied and yet incompletely understood protozoan disease of poultry. It is accounted for $5-10 \%$ mortality rate of chickens and an unknown loss due to reduced weight gain and feed efficiency, damage to the digestive tract, decreased egg production and lowered resistance of birds to other poultry diseases.

The underlying mechanisms of the host specificity are not well understood but most likely include genetic, nutritional, biochemical and immune factors. In addition to host specificity, a given Eimeria parasite only infects particular cell types or tissues in a given host (Lillehoj and Okamura, 2003). E. tenella is the ubiquitous and most pathogenic parasite responsible for caecal coccidiosis disturbing nutrient absorption and metabolism with high rate of mortality in poultry (Patra et al., 2010). It produces deviation in the various haematological components of the body (Panda et al., 1997; Patra et al., 2010). In broiler production, numerous anticoccidial drugs are used for prevention and control of coccidiosis. However, development of tolerance to these drugs has led to search for newer molecules and different classes of anticoccidials have been discovered and used from time to time. Hence, a comparative study on efficacy of different coccidiostats in broilers by inducing experimental infection of E. tenella was planned with evaluation of haematological alterations, if any.

\section{Materials and Methods}

Total of three hundred Cobb broiler chicks of either sex were procured at day-old age from Venky India Limited, Mogar, Gujarat. They were reared under coccidia-free conditions on battery cage system with standard protocols. The birds were randomly divided into 6 equal groups (T1 to T6) each of 50 birds. The chicks of T1, T2, T3 and T4 group were given Diclazuril (0.1\%), Salinomycin (12\%), Diclazuril + Salinomycin in shuttle programme, and Maduramicin $(1 \%)$ at a dose rate of $100 \mathrm{~g}, 50 \mathrm{~g}, 100+50 \mathrm{~g}$ and $50 \mathrm{~g}$ per $100 \mathrm{~kg}$ broiler feed as coccidiostats, respectively. Group T5 was kept as infected control and Group T6 as uninfected healthy control, both without coccidiostats. Birds of T1 to T5 groups were given experimental infection of 50,000 oocytes of E. tenella at three week of age.

Blood samples were taken randomly from 10 birds in each group from wing vein in citrated vials for haematology just before and again 1 week after experimental infection of $E$. tenella. Haemoglobin $(\mathrm{Hb}, \mathrm{g} \%)$ content was estimated by Sahli's acid haematin method and packed cell volume (PCV \%) by microhaematocrit method (Coles, 1986). Total erythrocytes count (TEC, $10^{6} / \mu \mathrm{l}$ ), total leukocytes count (TLC, $10^{3} / \mu 1$ ) and differential leukocyte count (DLC, $10^{3} / \mu \mathrm{l}$ ) were estimated as per Jain (1986). Data generated were analyzed statistically (Snedecor and Cochran, 1980) by using completely randomized design on SAS software version 20.00 .

\section{Results and Discussion}

Comparative efficacy of different coccidiostats on haematological values is given in Tables 1 and 2. Haematological values are the indicators of the pathological damage caused by the chemicals or infection. 


\section{Haemoglobin $(\mathrm{Hb})$}

All treatment groups had lower $\mathrm{Hb}$ value at 3 weeks of age, i.e. just before experimental infection, except Salinomycin group had nearly normal $\mathrm{Hb}$ value $(12.22 \pm 0.14 \mathrm{~g} / \mathrm{dl})$ similar to control group, which indicated better efficacy of Salinomycin. After experimental infection the $\mathrm{Hb}$ values were significantly decreased. The trend of decrease was highest in $\mathrm{T} 1$ group $(9.84 \pm 0.17 \mathrm{~g} / \mathrm{dl})$ followed by shuttle T3 $(9.96 \pm 0.16 \mathrm{~g} / \mathrm{dl})$, T4 $(10.76 \pm 0.19 \mathrm{~g} / \mathrm{dl})$ and $\mathrm{T} 2(11.51 \pm 0.29 \mathrm{~g} / \mathrm{dl})$ group among four treatment groups. Positive control T5 group showed significantly lowest $\mathrm{Hb}$ value $(8.54 \pm 0.07 \mathrm{~g} / \mathrm{dl})$ as compared to all treatment groups. Result indicated better efficacy of Salinomycin as compared to other coccidiostats. There was marked reduction in $\mathrm{Hb}$ values in the infected groups during acute phase of infection and the values returned to normal during recovery. There was no appreciable reduction in $\mathrm{Hb}$ values in the infected medicated group when compared to control group. The present findings are in conformity with the observations made by Turk (1985), Padmavathy and Muralidharam (1986), Ogbe et al., (2010) and Adamu et al., (2013) for E. tenella infection. The reduction in the value of haemoglobin observed in the infected group of birds might be attributed to haemorrhages in the caeca followed by development of caecal lesions. There may be injury to tissue and liberation of large quantities of histamine, which increase the local blood flow and also increase the permeability of capillaries and venules allowing large quantities of fluid to come out (Padmavathi and Muralidharan, 1986).

\section{Packed Cell Volume (PCV)}

Before experimental infection, PCV value was lowest in shuttle group T3 $(26.47 \pm 0.75 \%)$ and highest in Salinomycin group T2 (29.11 \pm $0.18 \%$ ). Both control groups had non- significantly higher values compared to treated groups. After experimental infection, the highest reduction was observed in $\mathrm{T} 1$ and $\mathrm{T} 3$ groups followed by $\mathrm{T} 4$ and $\mathrm{T} 2$ groups compared to pre-infection values. Result indicated better protection on PCV by Salinomycin among four coccidiostats. There was also significant reduction in PCV in postinfection positive control group compared to all treated post-infection groups indicating supportive efficacy of coccidiostats in birds. Significant reduction in PCV was also recorded by Stephens (1965). Similarly, Turk (1985) recorded fall in haematocrit value from the $5^{\text {th }}$ to $10^{\text {th }}$ day with E. necatrix infection. The present results were also comparable to those reported previously by number of authors for E. tenella infection (Padmavathi and Muralidharan, 1986; Panda et al., 1997; Kumar and Padmavathi, 2000; Jaipurkar et al., 2004; Ogbe et al., 2010; Adamu et al., 2013).

\section{Total Erythrocytes Counts (TEC)}

Before experimental infection, the highest mean TEC count $\left(10^{6} / \mu 1\right)$ was observed in T2 group $((2.36 \pm 0.03)$ followed by T1 $(2.33 \pm$ $0.02)$, T4 (2.30 \pm 0.03$)$ and T3 (2.29 \pm 0.02$)$ groups. Positive control group T5 (2.31 \pm 0.01 $\left.10^{6} / \mu 1\right)$ and negative control group T6 (2.32 \pm $0.01 \times 10^{6} / \mu 1$ ) had more or less similar values.

There was no significant difference in TEC counts between control and treatment groups. After experimental infection, there was significant reduction in TEC in all treatment groups with highest reduction in $\mathrm{T} 1$ followed by $\mathrm{T} 3, \mathrm{~T} 2$, and $\mathrm{T} 4$ groups as compared to $\mathrm{T} 6$ group (Table 1). In comparison with positive control group, all coccidiostats treated groups showed significant beneficial effect on TEC value with better efficacy of Maduramicin in term of less RBCs damage. Significant reduction in TEC was also recorded by above workers in birds affected with $E$. tenella infection. 
Table.1 Haematological values in different coccidiostats treated groups before and 1 week after experimental infection of E. tenella $(\mathrm{n}=10)$

\begin{tabular}{|c|c|c|c|c|c|c|c|c|c|c|c|c|}
\hline \multirow[t]{2}{*}{ Parameters } & \multirow{2}{*}{$\begin{array}{l}\mathbf{B I} \\
\mathbf{A I}\end{array}$} & \multicolumn{6}{|c|}{ Treatment groups } & \multirow{2}{*}{$\begin{array}{l}\text { Period } \\
\text { Mean }\end{array}$} & \multicolumn{2}{|c|}{$\mathbf{P}$} & \multicolumn{2}{|c|}{$\mathbf{T} \times \mathbf{P}$} \\
\hline & & $\mathbf{T}_{1}$ & $\mathbf{T}_{2}$ & $\mathbf{T}_{3}$ & $\mathbf{T}_{4}$ & $\mathbf{T}_{5}$ & $\mathbf{T}_{6}$ & & S Em & CD & S Em & CD \\
\hline \multirow{2}{*}{$\begin{array}{l}\text { TEC } \\
\left(10^{6} / \mu \mathrm{l}\right)\end{array}$} & BI & $2.33 \pm 0.03$ & $2.36 \pm 0.03$ & $2.29 \pm 0.02$ & $2.30 \pm 0.03$ & $2.31 \pm 0.01$ & $2.32 \pm 0.01$ & $2.32^{\mathrm{a}}$ & 0.03 & 0.08 & 0.07 & 0.20 \\
\hline & AI & $2.02 \pm 0.12$ & $2.13 \pm 0.12$ & $2.05 \pm 0.12$ & $2.11 \pm 0.12$ & $1.69 \pm 0.01$ & $2.42 \pm 0.01$ & $2.07^{b}$ & & & & \\
\hline \multirow[t]{2}{*}{ PCV $(\%)$} & BI & $28.28 \pm 0.55$ & $29.11 \pm 0.18$ & $26.47 \pm 0.75$ & $27.90 \pm 0.72$ & $28.80 \pm 0.15$ & $29.51 \pm 0.14$ & $28.35^{\mathrm{a}}$ & 0.23 & 0.65 & 0.57 & 1.59 \\
\hline & AI & $24.56 \pm 0.26$ & $28.05 \pm 1.10$ & $24.56 \pm 0.26$ & $26.72 \pm 1.00$ & $22.77 \pm 0.15$ & $30.24 \pm 0.12$ & $26.15^{\mathrm{b}}$ & & & & \\
\hline \multirow[t]{2}{*}{$\mathbf{H b}(\mathbf{g} \%)$} & $\mathrm{BI}$ & $11.16 \pm 0.23$ & $12.22 \pm 0.14$ & $11.43 \pm 0.27$ & $11.63 \pm 0.32$ & $12.35 \pm 0.06$ & $12.42 \pm 0.11$ & $11.87^{\mathrm{a}}$ & 0.08 & 0.22 & 0.19 & 0.54 \\
\hline & AI & $9.84 \pm 0.17$ & $11.51 \pm 0.29$ & $9.96 \pm 0.16$ & $10.76 \pm 0.19$ & $8.54 \pm 0.07$ & $12.75 \pm 0.05$ & $10.56^{\mathrm{b}}$ & & & & \\
\hline \multirow{2}{*}{$\begin{array}{l}\text { TLC } \\
\left(10^{3} / \mu \mathrm{l}\right)\end{array}$} & BI & $23.14 \pm 0.21$ & $22.91 \pm 0.13$ & $23.04 \pm 0.12$ & $22.70 \pm 0.20$ & $21.51 \pm 0.06$ & $21.51 \pm 0.06$ & $22.47^{\mathrm{a}}$ & 0.15 & 0.42 & 0.37 & 1.04 \\
\hline & AI & $41.36 \pm 0.46$ & $33.36 \pm 0.39$ & $37.56 \pm 0.99$ & $34.66 \pm 0.13$ & $52.71 \pm 0.38$ & $21.47 \pm 0.05$ & $36.86^{\mathrm{b}}$ & & & & \\
\hline \multirow{2}{*}{$\begin{array}{l}\text { Heterophills } \\
\left(10^{3} / \mu \mathrm{l}\right)\end{array}$} & BI & $9.84 \pm 0.09$ & $9.74 \pm 0.06$ & $9.90 \pm 0.08$ & $9.56 \pm 0.16$ & $8.40 \pm 0.09$ & $8.29 \pm 0.03$ & $9.29^{\mathrm{a}}$ & 0.09 & 0.24 & 0.21 & 0.59 \\
\hline & AI & $18.07 \pm 0.07$ & $14.92 \pm 0.27$ & $16.52 \pm 0.56$ & $15.34 \pm 0.26$ & $17.49 \pm 0.14$ & $7.44 \pm 0.02$ & $14.96^{\mathrm{b}}$ & & & & \\
\hline \multirow{2}{*}{$\begin{array}{l}\text { lymphocytes } \\
\left(10^{3} / \mu \mathrm{l}\right)\end{array}$} & BI & $9.53 \pm 0.16$ & $9.34 \pm 0.08$ & $9.42 \pm 0.09$ & $9.38 \pm 0.08$ & $9.28 \pm 0.12$ & $9.32 \pm 0.07$ & $9.38^{\mathrm{a}}$ & 0.13 & 0.36 & 0.31 & 0.87 \\
\hline & AI & $19.14 \pm 0.47$ & $13.90 \pm 0.57$ & $16.66 \pm 0.62$ & $15.06 \pm 0.29$ & $30.11 \pm 0.29$ & $9.92 \pm 0.01$ & $17.47^{\mathrm{b}}$ & & & & \\
\hline \multirow{2}{*}{$\begin{array}{l}\text { Monocytes } \\
\left(10^{3} / \mu \mathrm{l}\right)\end{array}$} & BI & $0.72 \pm 0.02$ & $0.68 \pm 0.02$ & $0.73 \pm 0.02$ & $0.69 \pm 0.02$ & $0.75 \pm 0.01$ & $0.75 \pm 0.01$ & $0.72^{\mathrm{a}}$ & 0.02 & 0.06 & 0.05 & 0.15 \\
\hline & AI & $0.49 \pm 0.06$ & $0.61 \pm 0.08$ & $0.65 \pm 0.10$ & $0.61 \pm 0.03$ & $0.67 \pm 0.11$ & $0.90 \pm 0.02$ & $0.65^{b}$ & & & & \\
\hline \multirow{2}{*}{$\begin{array}{l}\text { Eosinophills } \\
\left(10^{3} / \mu \mathrm{l}\right)\end{array}$} & BI & $0.77 \pm 0.02$ & $0.82 \pm 0.01$ & $0.75 \pm 0.03$ & $0.80 \pm 0.01$ & $0.84 \pm 0.01$ & $0.81 \pm 0.01$ & $0.80^{\mathrm{a}}$ & 0.01 & 0.05 & 0.05 & 0.13 \\
\hline & $\mathrm{AI}$ & $1.84 \pm 0.07$ & $1.68 \pm 0.08$ & $1.80 \pm 0.08$ & $1.46 \pm 0.07$ & $2.37 \pm 0.04$ & $0.93 \pm 0.01$ & $1.68^{b}$ & & & & \\
\hline \multirow{2}{*}{$\begin{array}{l}\text { Basophills } \\
\left(10^{3} / \mu \mathrm{l}\right)\end{array}$} & $\mathrm{BI}$ & $2.28 \pm 0.02$ & $2.34 \pm 0.03$ & $2.25 \pm 0.02$ & $2.28 \pm 0.03$ & $2.26 \pm 0.02$ & $2.33 \pm 0.03$ & $2.29^{\mathrm{a}}$ & 0.02 & 0.05 & 0.04 & 0.12 \\
\hline & AI & $1.82 \pm 0.05$ & $2.25 \pm 0.04$ & $1.94 \pm 0.08$ & $2.18 \pm 0.03$ & $2.06 \pm 0.07$ & $2.28 \pm 0.05$ & $2.09^{\mathrm{b}}$ & & & & \\
\hline
\end{tabular}

The means bearing different superscript within the column for BI (before infection) \& AI (after infection) differ significantly (P<0.05). 
Table. 2 Haematological pooled values (Mean \pm SE) in different treatment groups $(n=10)$

\begin{tabular}{|c|c|c|c|c|c|c|c|c|}
\hline \multirow[t]{2}{*}{ Parameters } & \multirow[t]{2}{*}{$T_{1}$} & \multirow[t]{2}{*}{$\mathbf{T}_{2}$} & \multirow[t]{2}{*}{$\mathbf{T}_{3}$} & \multirow[t]{2}{*}{$T_{4}$} & \multirow[t]{2}{*}{$T_{5}$} & \multirow[t]{2}{*}{$T_{6}$} & \multicolumn{2}{|c|}{$\mathbf{T}$} \\
\hline & & & & & & & S Em & CD \\
\hline $\operatorname{TEC}\left(10^{6} / \mu \mathrm{l}\right)$ & $2.18^{\mathrm{b}}$ & $2.25^{\mathrm{ab}}$ & $2.17^{\mathrm{b}}$ & $2.21^{\mathrm{b}}$ & $2.00^{\mathrm{c}}$ & $2.37^{\mathrm{a}}$ & 0.05 & 0.14 \\
\hline PCV $(\%)$ & $26.42^{\text {cd }}$ & $28.58^{b}$ & $25.52^{d}$ & $27.31^{\mathrm{c}}$ & $25.79^{d}$ & $29.88^{\mathrm{a}}$ & 0.40 & 1.12 \\
\hline Hb (g\%) & $10.50^{\mathrm{d}}$ & $11.87^{\mathrm{b}}$ & $10.70^{\mathrm{d}}$ & $11.20^{\mathrm{c}}$ & $10.45^{\mathrm{d}}$ & $12.59^{\mathrm{a}}$ & 0.14 & 0.38 \\
\hline $\operatorname{TLC}\left(10^{3} / \mu \mathrm{l}\right)$ & $32.25^{\mathrm{b}}$ & $28.13^{\mathrm{d}}$ & $30.30^{c}$ & $28.68^{\mathrm{d}}$ & $37.11^{\mathrm{a}}$ & $21.49^{\mathrm{e}}$ & 0.26 & 0.73 \\
\hline Heterophills $\left(10^{3} / \mu \mathrm{l}\right)$ & $13.95^{\mathrm{a}}$ & $12.33^{\mathrm{c}}$ & $13.21^{\mathrm{b}}$ & $12.45^{\mathrm{c}}$ & $12.95^{\mathrm{b}}$ & $7.87^{\mathrm{d}}$ & 0.15 & 0.42 \\
\hline lymphocytes $\left(10^{3} / \mu \mathrm{l}\right)$ & $14.34^{\mathrm{b}}$ & $11.62^{d}$ & $13.04^{\mathrm{c}}$ & $12.22^{\mathrm{d}}$ & $19.70^{\mathrm{a}}$ & $9.62^{\mathrm{e}}$ & 0.22 & 0.62 \\
\hline Monocytes $\left(10^{3} / \mu \mathrm{l}\right)$ & $0.60^{\mathrm{b}}$ & $0.64^{\mathrm{b}}$ & $0.69^{b}$ & $0.65^{\mathrm{b}}$ & $0.71^{\mathrm{b}}$ & $0.83^{\mathrm{a}}$ & 0.04 & 0.10 \\
\hline Eosinophills $\left(10^{3} / \mu \mathrm{l}\right)$ & $1.31^{\mathrm{b}}$ & $1.25^{\mathrm{b}}$ & $1.28^{\mathrm{b}}$ & $1.13^{\mathrm{c}}$ & $1.59^{\mathrm{a}}$ & $0.87^{\mathrm{d}}$ & 0.03 & 0.09 \\
\hline Basophills $\left(10^{3} / \mu \mathrm{l}\right)$ & $2.05^{\mathrm{d}}$ & $2.30^{\mathrm{a}}$ & $2.09^{\mathrm{cd}}$ & $2.23^{\mathrm{ab}}$ & $2.16^{\mathrm{bc}}$ & $2.31^{\mathrm{a}}$ & 0.03 & 0.08 \\
\hline
\end{tabular}

The means bearing different superscripts within the row differ significantly $(\mathrm{P}<0.05)$.

However, Stephens et al., (1967) found significant increase in erythrocyte count with E. acervulina infection at $6^{\text {th }}, 10^{\text {th }}$ and $14^{\text {th }}$ day of inoculation. The reduction observed in TEC during the acute phase of infection is due to haemorrhage.

\section{Total Leucocytes Counts (TLC)}

Just before experimental infection, TLC counts were in the range of 22.70 to 23.14 $\times 10^{3} / \mu 1$ among all four treatment groups, while the TLC counts were significantly lower $\left(21.51 \pm 0.06 \times 10^{3} / \mu \mathrm{l}\right)$ in both the control groups. After experimental infection TLC counts were significantly increased in four groups than the pre-infection values. Highest count $\left(10^{3} / \mu \mathrm{l}\right)$ was observed in $\mathrm{T} 1$ group (41.36 \pm 0.46$)$ followed by T3 (37.56 \pm $0.99)$, T4 (34.66 \pm 0.13$)$ and T2 (33.36 \pm $0.39)$ groups. TLC count of post-infection positive control group was $(52.71 \pm 0.38$ $\left.\times 10^{3} / \mu \mathrm{l}\right)$ significantly higher than the preinfection value of same group $(21.51 \pm 0.06$ $\times 10^{3} / \mu 1$ ). The result indicated better efficacy of Salinomycin followed by Maduramicin in E. tenella infection. Significant increase in TLC has also been reported by Padmavathi and Muralidharan (1986), Panda et al., (1997), Kumar and Padmavathi (2000), Jaipurkar et al., (2004) and Ogbe et al., (2010). Adamu et al., (2013) also reported similar findings of higher TLC with increased numbers of lymphocytes, eosinophils and heterophils in E. tenella and $E$. brunetti infected broilers. The increased total leucocytes count in coccidia-affected birds might be due to suppressed body immune system from the infection (Stephen, 1965). This increase was suggestive of increase leucopoiesis as a first step of defence mechanism to infection (Padmavathi and Muralidharan, 1986).

\section{Differential Leucocyte Counts (DLC)}

At 3 weeks of age, all treatment groups had 1 to $1.5 \times 10^{3} / \mu 1$ heterophils, which were higher as compared to both control groups. After experimental infection heterophills counts $\left(10^{3} / \mu 1\right)$ were significantly increased in all treatment groups with highest increase in $\mathrm{T} 1$ group (18.07 \pm 0.07$)$ followed by T3 (16.52 \pm $0.56), \mathrm{T} 4(15.34 \pm 0.26)$ and $\mathrm{T} 2(14.92 \pm$ 0.27 ) groups suggesting better efficacy of Salinomycin and Maduramicin. The increase in the heterophills was observed because heterophils also contain a variety of granules that contribute to the first line host defence against bacteria, fungi, protozoa and some viruses. Acute or chronic inflammatory disease is the predominant cause of monocytosis or heterophilia in pet birds (Irizaary-Rovira, 2004) because monocytes, 
macrophages and dendritic cells are important hematopoietic cells that play critical role in defence and in maintaining homeostasis.

Slightly higher lymphocytic values were observed in all treatment groups as compared to control group at the age of 3 weeks, but significant increase in lymphocytes count $\left(10^{3} / \mu 1\right)$ was observed after experimental infection with highest increase in T1 group $(19.14 \pm 0.47)$ followed by T3 (16.66 \pm 0.62$)$, $\mathrm{T} 4(15.06 \pm 0.29)$ and T2 (13.90 \pm 0.57$)$ groups. Post-infection positive control group showed significant increase in lymphocytes count $\left(30.11 \pm 0.2910^{3} / \mu \mathrm{l}\right)$ as compared to preinfection value $\left(9.28 \pm 0.12 \times 10^{3} / \mu \mathrm{l}\right)$. Better efficacy of Salinomycin followed by Maduramicin was seen in infected birds compared to Diclazuril in terms of pathological damage. The increase in the lymphocyte count may be attributed to the effect of the inflammation of the caeca and intestine. Chronic antigenic stimulation may result in a greatly expanded circulating lymphocyte pool because the primary functions of the lymphocytes are immunological response, humoral antibody formation and cell mediated immunity (Irizaary-Rovira, 2004).

Coccidiostats used in the experiment decreased monocytes counts after infection with lowest decrease in Salinomycin treatment. There was more decrease in post-infection monocyte value in positive control group $\left(0.08 \times 10^{3} / \mu \mathrm{l}\right)$. Padmavati and Murlidharan (1986) also reported decrease in monocytes count at 7-day post-experimental infection of E. tenella.

E. tenella infection at 3 weeks of age caused significant increase in eosinophilic count $\left(10^{3} / \mu \mathrm{l}\right)$ with highest value in T1 group $(1.84 \pm$ $0.07)$ followed by shuttle group T3 (1.80 \pm $0.08), \mathrm{T} 2(1.68 \pm 0.08)$ and $\mathrm{T} 4(1.46 \pm 0.07)$. Significant increase of eosinophilic count observed in T5 positive control group (2.37 \pm $\left.0.04 \times 10^{3} / \mu \mathrm{l}\right)$ as compared to treated groups indicated more damage by infection which can be reduced by coccidiostat treatment. Similar increase of eosinophils was reported by Adamu et al., (2013). Eosinophilia rarely occurs in birds, but may be associated with parasitism and is known to interact with homocytotropic antibodies (IgE and $\mathrm{IgG}$ ), mast cells and basophils. The antibody and $\mathrm{T}$ lymphocytes provide specificity to the reaction and the $\operatorname{IgE}$ on mast cells attracts eosinophils to modulate the inflammatory reaction (Irizaary-Rovira, 2004)

Basophils counts $\left(10^{3} / \mu \mathrm{l}\right)$ were more or less similar in both control as well as all four treatment group at 3 weeks of age, but more reduction was observed in $\mathrm{T} 1(1.82 \pm 0.05)$ and $\mathrm{T} 3(1.94 \pm 0.08)$ groups as compared to T2 $(2.25 \pm 0.04)$ and T4 $(2.18 \pm 0.03)$ groups after experimental infection indicating better efficacy of Salinomycin and Maduramicin. Significant reduction was observed in post-infection control group $\left(2.06 \pm 0.07 \times 10^{3} / \mu 1\right)$ as compared to preinfection value $\left(2.26 \pm 0.02 \times 10^{3} / \mu 1\right)$. Padmavathi and Muralidharan (1986) however did not find basophills after $7^{\text {th }}$ day of experimental E. tenella infection of 50,000 oocysts.

\section{Acknowledgement}

The authors thank Principal Scientist and Head, Poultry Complex, and Principal and Dean, College of Veterinary Science \& AH, Anand for providing the necessary facilities.

\section{Conflict of Interest}

All authors declare no conflict of interest.

\section{References}

Adamu, M., Chaiwat, B., Nirat, G. and Montakan, V. (2013). Haematological, biochemical and histopathological changes caused by coccidiosis in chickens., Kasetsart J. Nat. Sci., 47: 238246.

Bootwalla, S. (2005). Poultry population in the Asian sub-continents. World Poult, 21(4):10-12. 
Chakarabarti Amalendu (1989): Practice of Poultry Medicine. Kalyani Publisher Ltd., New Delhi, India, pp.22-34.

Coles, E.H. (1986). Veterinary Pathology. $4^{\text {th }}$ Edn. W.B. Saunders, London.

Irizaary-Rovira, A.R. (2004). Avian and reptile clinical pathology (Avian hematology \& biochemical analysis), Section XI, pp. 282-313. In R.L. Cowell, (ed.).Veterinary Clinical Pathology Secrets. Elsevier Inc. St. Louis, MO, USA.

Jain, N.C. (1986). Schalm's Veterinary Haematology. $4^{\text {th }}$ Edn. Lea and Febiger, 600, Washington Square, Philadelphia, USA.

Jaipurkar, S.G., Deshpande, P.D., Narladkar, B.W., Rajurkar, S.R. and Kulkarni, G.B. (2004). Caecal coccidiosis in broiler chicks: haematological, pathological changes during treatment with herbal antidiarrhoels. J. Vet. Parasitol. 18 (2): 135-138.

Kumar Uday, M. and Padmavathi, P. (2000). Interaction of aflatoxin $\mathrm{B}_{1}$ and Eimeria tenella infection in broiler chickens. $J$. Parasitol., 14: 39-43.

Lillehoj, H. and Okamura, M. (2003). Host immunity and vaccine development to coccidian and Salmonella infections in chicken. J. Poult. Sci. 10: 151-153.

Ogbe, A.O., Atawodi, S.E. Abdu, P.A. Oguntayo, B.O. and Noel Dus. (2010). Oral treatment of Eimeria tenella-infected broilers using aqueous extract of wild mushroom (Ganoderma Sp): Effect on haematological parameters and histopathology lesions. Afr. J. Biotechnol., 9: 8923-8927.

Padmavathi, P. and Muralidharan, S.R.G. (1986). Alteration in haematological parameters in chicken during Eimeria tenella infection. Indian Vet. J., 63: 716722.

Panda, D.N., Mishra, A., Misra, S.C. and Mishra, U.K. (1997). Comparative haematological and clinicopathological changes between Eimeria tenella infected and supercox treated broiler birds. Indian Vet. J., 74: 206-209.

Patra, G., Rajkhow, T.K., Ali, M.A., Tiwari, J.G. and Sailo, L. (2010). Studies on clinical, gross, histopathological and biochemical parameters in Broiler Birds suffered from Eimeria necatrix infection in Aizwal District of Mizoram, India. Int. J. Poul. Sci., 9(12):1120-1124.

Saima, M.Z., Jabbar, M.A., Mehmud, A., Abbas, M.M. and Mahmood, A. (2010). Effect of lysine supplementation in low protein diets on the performance of growing broilers. Pakistan Vet. J., 30: 1720.

Snedecor, G.W. and Cochran, W.G. (1980). Statistical Methods. $8^{\text {th }}$ Ed. Iowa State Univ. Press, Ames. Iowa, USA.

Stephens, J.F., Komalski, L.M. and Borst, W.J. (1967). Some physiological effects of coccidiosis caused by Eimeria maxima in young chickens. J. Parasitol., 53: 176179.

Stephens, J.K. (1965). Some physiological effects of coccidiosis caused by Eimeria necatrix in the chicken. J. Parasitol., 51: 331-335.

Turk, D.E. (1985). Macro-elements in the circulation of coccidiosis infected chicks. Poult. Sci., 65: 462-468.

\section{How to cite this article:}

Hirani, N.D., J.J. Hasnani, S.S. Pandya and Patel, P.V. 2018. Haematological Changes in Broiler Birds with Induced Caecal Coccidiosis following Prophylaxis with Different Coccidiostats. Int.J.Curr.Microbiol.App.Sci. 7(04): 1094-1100. doi: https://doi.org/10.20546/ijcmas.2018.704.119 